Volume 5, Issue 2

September 2012

\title{
Who's Afraid of the Rubber Man? Perversions and Subversions of Sex and Class in American Horror Story
}

TOSHA TAYLOR, Loughborough University

\begin{abstract}
This article examines representations of sexuality in the first series of American Horror Story. Though the series presents many supernatural villains and is, on the surface, a typical haunted house story, it often creates its sense of horror through deployment of sexual tropes. The haunted house story itself is traditionally linked to notions of sexuality and class (Bailey, 1999; Ellis, 1989); this paper argues that American Horror Story (2011- ) emphasizes that link and manipulates such notions to explore their place in contemporary American thought and entertainment. Analysis of Kristeva's and Creed's linking of Horror to sexuality demonstrates that the series builds its sense of horror on abjection. Ghosts and other supernatural creatures in the series, this article contends, are merely accoutrements to a plot that is steeped in sexual anxieties. Grounded in Foucault's characterization of sanctioned sexual repression as 'a sentence to disappear' and 'an injunction to silence' (Foucault, 1978: 4), this discussion of American Horror Story studies the show's explicit references to, and depictions of, sexual practices that are typically neglected on mainstream television. Finally, this article questions the show's success in subverting popular opinions about aberrant sexualities.
\end{abstract}

\section{KEYWORDS}

American Horror Story, BDSM, Gothic fiction, haunted house, Horror, queer television, sexuality, Telefantasy

Though programs boasting Science Fiction and Fantasy elements seem far more numerous, primetime television in the US has not avoided Horror. Shows like Twin Peaks (1990-1991) and The X-Files (1993-2002) still enjoy a niche viewership, and even Dr. Who (1963-1989, 2005- ), which receives a regular airing on BBC America, has dabbled more than once in the grotesque. Debuting in the fall of 2011 on FX, American Horror Story (2011-, hereafter AHS) is far from the first successful Horror serial, but it may be one of the most insightful. What makes it unique, however, is not its genre or its plot elements, but rather, its exploration of what constitutes $\mathrm{H} /$ horror. 
Volume 5, Issue 2

September 2012

Lead actor Dylan McDermott (who plays Ben Harmon) sums up his character's dilemma succinctly: 'One of the biggest problems I have is that my wife and my girlfriend are both pregnant. At the same time... It's every man's worst nightmare, I would say' (qtd. in Freydkin, 2011). McDermott's description is a humorous understatement, but not an inaccurate one. $A H S$ features a motley crew of ghosts, deformed figures, and even a demonic baby, but its horror revolves around more domestic and realistic concerns - infidelity, rape, and perceived sexual deviance.

The series' plot is neither simple nor completely linear. Through flashbacks juxtaposed against present-day events, the series recounts the history of an Edwardian-style home in the Los Angeles suburbs, colloquially known as the Murder House due to the violent ends its inhabitants tend to meet. In the present, Ben and Vivien Harmon (Connie Britton), along with their teenage daughter, Violet (Taissa Farmiga), move cross-country from Boston to LA in an attempt to distance themselves from events that have recently endangered their marriage, including Ben's affair with one of his students and Vivien's miscarriage. While the house seems to offer the fresh start the family desires, they soon find themselves prey to supernatural forces. One of Ben's patients, a violent teenager named Tate (Evan Peters), is in actuality a ghost with a romantic interest in Violet. Meddling neighbour Constance (Jessica Lange) and daughter Addie (Jamie Brewer), while still alive themselves, prove to be fully aware of the supernatural presences in the house and regularly engage with them. Ghosts of the home's previous inhabitants arrive both day and night to survey what they feel is still their territory; their numbers grow when Ben's vindictive, pregnant lover, Hayden (Kate Mara), is killed on the grounds by Larry (Denis O'Hare), another previous inhabitant who managed to escape the house alive but horribly disfigured. An even more sinister figure threatens to arrive when Vivien becomes pregnant with twins by a fetish suit-wearing villain known as the Rubber Man, whom Vivien erroneously believed to be Ben when the conception occurred. Other dramatis personae include the ghosts of Charles and Nora Montgomery (Matt Ross and Lily Rabe) - the home's first inhabitants, Chad and Patrick (Zachary Quinto and Teddy Sears) - a gay couple who lived in the house before the Harmons, and Moira (Frances Conroy) - a housekeeper whom women see as an old, half-blind crone and men see as a young, voluptuous, hypersexual siren. As the subplots of each of these characters converge, the ghosts band together under a common goal - of killing Vivien and stealing her newborn children.

\section{Unholy Ground}

Despite the risk of alienating television audiences through the show's BDSM-steeped advertising campaign, $A H S$ 's pilot was a success, drawing in a reported 3.2 million viewers and receiving the second highest rating for any FX original pilot amongst viewers aged eighteen to forty-nine (Stack, 2011). Such frank depictions of sexuality, especially when 
pertaining to practices considered deviant, are still relatively unusual on American television, and perhaps because of that, $A H S$ certainly caught viewers' attention.

Co-creator Ryan Murphy, best known for teen musical series Glee (2009- ) and sensual plastic surgery drama Nip/Tuck (2003-2010), makes no pretences about $A H S$ 's focus on sexuality: 'All my favorite horror movies were based in sex,' he told Entertainment Weekly, contrasting AHS with the current trend in Horror, which Murphy describes as 'violent snuff porn'1 (qtd. in Stack, 2011). So entrenched in sexuality is the series that Murphy even cites Dylan McDermott's willingness to perform a scene in which his character weeps profusely whilst masturbating as one of the reasons for the actor's casting (Stack, 2011). With the show's pilot episode suggesting - and, often, explicitly depicting - adultery, autoeroticism, male same-sex relationships, BDSM, and rape, the tone for the rest of the series is set immediately, and it is clear from the outset that the Murder House was built upon the intersection of sexuality and horror.

A continued connection between America's Christian right and national politics has ensured that sexuality remains a topic of concern in entertainment media (Arthurs, 2004: 22-23). The accidental exposure of Janet Jackson's nipple during the Super Bowl halftime show in 2004 prompted a record 540,000 complaints to the FCC (Horovitz, 2005). More recently, Murphy's Glee has come under fire from Christian and conservative groups, including Christwire and the Parents' Television Council, for positive depictions of teen homosexuality. Recent conservative interests in the US have made women's and, respectively, gay sexuality the sites of much anxiety, both in actual practice and fictional representations. A number of states have put forth legislation that would severely limit the availability of both contraception and abortion procedures. The demonization of birth control has most recently been represented in the public eye in February 2012, when (in)famous conservative radio host Rush Limbaugh referred to Sandra Fluke, a law student who advocates requiring insurance companies to provide coverage for contraception, as a 'slut.' In Utah, Mississippi, and Georgia, conservative legislators have enacted or tried to enact laws that would allow for investigations into the causes of miscarriages due to fears that women, perhaps because of the unavailability of abortion, will induce them; under such bills, induction of miscarriage would be a criminal act. Texas governor and former presidential hopeful Rick Perry, who opposes the teaching of safe sex practices in schools, suffered some embarrassment following findings that Texas, with over 94\% schools offering abstinence-only sex education (Wiley and Wilson, 2009: 2), has achieved the nation's fourth-highest teen pregnancy rate (Guttmacher Institute, 2010, 2012: 13). A disturbing rash of teen suicides in recent years, often related to sexualitybased bullying, is believed to be linked to the neo-evangelical movement; in the case of nine suicides (and more attempts) in a two-year span in one school district, the district's former representative, Michele Bachmann, is sometimes specifically blamed for the 'extreme antigay climate' in which these teens were persecuted (Erdley, 2012; Mencimer, 2011). ${ }^{2}$ Continued judiciary and political debate on the Defence of Marriage Act (DOMA) indicates that, while same-sex marriage is finding increasing support in a number of states, it remains a 
Volume 5, Issue 2

September 2012

topic of contention for politicians and voters. In this volatile political environment, representations of sexuality on television have been increasingly scrutinised. With such realistic sites of anxiety in the series, ghosts and a Frankenstein-esque creation in the basement seem almost extraneous.

Indeed, the darkest moments of the series are those that invoke everyday horrors, often without explicitly deploying supernatural elements. References to infamous, real-life murder cases (including that of the Lindbergh baby, the Black Dahlia, and perhaps even that of Matthew Shepard) are reminders that, while the show itself is fiction, some of the horrors depicted have, in fact, happened in real life. Moreover, some seem to bespeak a paternalistic anxiety that has become a motif both in Horror fiction and in real-life media; the question of how the family patriarch failed to protect his charges. ${ }^{3}$ Echoing such concerns, Violet even doubts Ben's ability to protect her (1.06, 'Piggy Piggy'). Concerns over women's sexual agency, controlled by men or allowed to run rampant, appear throughout the series.

Originating at a time when abortion was illegal, the Murder House becomes a secret abortion clinic when Dr. Charles Montgomery, losing his legitimate medical practice due to drug addiction, needs other means to finance his and Nora's lavish lifestyle. Moira is made into a ghost when, blamed for her own rape at the hands of Constance's husband, Hugo Langdon (Eric Close), Constance kills her (1.03, 'Murder House'). By interpreting this rape as mutual seduction, Constance enacts the popular misogynistic paradigm in which rape victims are seen as "asking for it." Similarly, when she fears that her boyfriends have been sexually involved with her daughter, Addie, she does not consider the possibility that they have been taking advantage of the young woman's condition (Addie has Down syndrome), but rather accuses Addie of trying to steal them away (1.04, 'Halloween: Part I'). When prenatal testing reveals that one of Vivien's twins is not Ben's, Vivien realizes that the Rubber Man was not her husband and that she has been raped by an intruder; despite her protestations of rape, Ben immediately accuses her of adultery and verbally abuses her (1.09, 'Spooky Little Girl').

Even when it is not making reference to larger social problems and infamous crimes, $A H S$ roots a great deal of its conflict in more intimate issues of sex and the family. When the series opens, Vivien has recently suffered a pregnancy resulting in stillbirth, and both that pregnancy and the next one are a cause of concern for the Harmons and those around them due to Vivien's age. Though he seems to love his wife, Ben is a compulsive adulterer, whose infidelity ultimately results in an extramarital pregnancy. Violet's relationship with Tate at first appears to typify the 'good girl' dating the 'bad boy' trope, and becomes steadily darker as it is revealed that Tate is A) a murderer, B) dead, and C) the show's leading villain, the Rubber Man. Tracing the house's ownership back, one sees that domestic betrayals are something of a tradition for the home. The house's owners prior to the Harmons, Chad and Patrick, clearly attempted an idealised middle-class domestic life, but were thwarted by Patrick's infidelity, much in the same way that the Harmons' new life together will be. Before Chad and Patrick, the house was the setting for the breakup of Larry's marriage; in retaliation for her husband's infidelity, Lorraine Harvey (Rebecca Wisocky) sets fire to their 
children and herself. Finally, in the 1920s, Charles and Nora Montgomery's marriage collapsed due to Charles's ether addiction and morbid obsession; ultimately, their child is murdered when the boyfriend of a patient learns they performed an abortion for his lover without his consent.

However, the sexual nature of the house's many hauntings is not unique to $A H S$. Rather, sexualized haunting, necessarily linked to notions of class, is deeply rooted within the Gothic. Though much of the conventions that define the Gothic and which relate sexuality to the haunted house narrative have their basis in eighteenth-century European representations and nineteenth-century American reinterpretations, Foucault assures us that the class structures which ultimately gave rise to such phenomena are not at all a thing of the past (Foucault, 1978: 47). Furthermore, as this article will discuss, $A H S$ 's conformity to conventional Gothic tropes derives from much of the same concerns regarding sexuality and class in which those tropes originated. With sexual knowledge and practice increasingly regulated in both Victorian England and the United States, Foucault notes its relocation:

Sexuality was carefully confined; it moved into the home. The conjugal family took custody of it and absorbed it into the serious function of reproduction. On the subject of sex, silence became the rule. The legitimate procreative couple laid down the law. The couple imposed itself as model, enforced the norm, safeguarded the truth, and reserved the right to speak while retaining the principle of secrecy. A single locus of sexuality was acknowledged in social space as well as at the heart of every household, but it was a utilitarian and fertile one: the parents' bedroom. (Ibid.: 3)

Taken from the bawdy streets and situated (and hidden) firmly within the bedroom of the heterosexual couple, sexuality becomes something that can be regulated. With middle class heterosexual awareness of sexual practice accepted and confined to the bedroom, sexuality can be explored, but only insofar as those explorations conform to monogamous heterosexual prescriptions. The sexual practices of 'children, mad men and women and criminals; the sensuality of those who did not like the opposite sex; reveries, obsessions, petty manias, or great transports of rage,' conversely, became the subject of legal and social scrutiny (Ibid.: 38-39). We may note that Foucault's list of unsavoury sexual characters can be accurately applied to the cast of $A H S$, with its motley crew of ghostly children, psychologically disturbed women, adulterous men, rapists, and murderers.

It is precisely these aberrant forms of sexuality that often feature in Gothic fiction. Juxtaposed against the middle-class, monogamous heterosexuality, such forms are imbued with a sense of abjection (Kristeva, 1982). That these aberrant sexualities are manifest primarily through dead and disfigured characters further suggests the abject, for Kristeva identifies the dead body as "the utmost of abjection. It is death infecting life... Imaginary uncanniness and real threat' (Ibid.: 4). Kristeva asserts that abjection is caused by 'what disturbs identity, system, order. What does not respect borders, positions, rules... The traitor, 
the liar, the criminal with a good conscience, the shameless rapist, the killer who claims he is a savior' (Ibid.: 4). The threat posed by the abject, according to Kristeva, links death to sexuality (Ibid.: 13). Depictions of aberrant sexualities confront the viewer, forcing them to recognize that which would otherwise be unseen and unspoken.

$A H S$ owes much of its horror elements to exposing that which is normally kept secret, whether by social imperative or creators' preferences. Explicit depictions of "aberrant" sexualities have long suffered from a 'sentence to disappear, but also... an injunction to silence, an affirmation of nonexistence,' (Foucault, 1978: 4). By bringing aberrant sexualities and related issues of class to light, the series participates in what Foucault describes as an empowering agency: 'If sex is repressed, that is, condemned to prohibition, nonexistence, and silence, then the mere fact that one is speaking about it has the appearance of a deliberate transgression. A person who holds forth in such language places himself to a certain extent outside the reach of power; he upsets established law; he somehow anticipates the coming freedom' (Ibid.: 6). AHS creates a sense of horror through bringing such practices to light through the use of Kristevan abjection, grounding both accepted and aberrant sexual practices in threats of murder and the appearance of the dead.

\section{"There's an intruder in my house..."}

In Gothic fiction, the haunted house is made frightening not simply because sinister forces are present, but because of where they are present. The home is expected to be a place of safety, a physical divider between the dangers and influences of the outside world and the virtues of those living within its walls. Violations of that barrier are interpreted as intimate assaults, sometimes even coded in sexual language.

In its first episode, $A H S$ immediately establishes the house as metaphor for sexuality. Visiting her OBGYN following a stillbirth, Vivien is visibly disconcerted to hear the doctor describing the female body as a house. Vivien denies this objectification; one scene change later, hearing Addie moving within the home, Vivien calls the police to report 'an intruder in my house.' While the line is a literal reference to an unwelcome presence in Vivien's home, the fact that Vivien is raped at the episode's end lends it an ominous quality. Though it does not ultimately culminate in rape, the threat of sexual violence in the opening scene of the aptly entitled 'Home Invasion,' (1.02) emphasizes the metaphor by having an intruder and murderer force his victim to strip while she protests that she is a virgin. Vivien's pregnancy, the product of both consensual sex with her husband and her rape by the Rubber Man, places a demonic intruder inside the "house" of her body. The Murder House is haunted by ghosts; Vivien's body is haunted by a monstrous creature. Recalling Kristeva's association of abjection with the corpse and with that which crosses boundaries, Barbara Creed describes the womb as the means by which the living are inextricably linked to the abject: 'Horror films that depict monstrous births play on the inside/outside distinction in order to point to the inherently monstrous nature of the womb as well as the impossibility of ever completely 
Volume 5, Issue 2

September 2012

banishing the abject from the human domain' (Creed, 1993: 49). Furthermore, she writes that 'The womb represents the utmost abjection for it contains a new life form which will pass from inside to outside bringing with it traces of contamation - blood, afterbirth, faeces' (Ibid.), and in Vivien's case, death itself. Containing the child of a ghost just as the Murder House's basement contains the grotesque creature known as the Infantata, Vivien's womb begins to mirror the house itself, enacting symbolism Creed finds 'central to the iconography of the horror film' (Ibid.: 55).

The house metaphor of $A H S$ does not merely extend to women's bodies, however. Where female characters are threatened by human, or human-appearing, intruders, Chad expresses fear that Patrick's infidelity will 'bring disease into this house' (1.08, 'Rubber Man'). An uninvited party (at least as far as Chad is concerned) has intruded upon the two men's relationship, bringing with him the threat of an unwanted intrusion of the body. Vivien's body becomes pregnant as a result of her intruder; Chad worries that his body will become diseased because of his. Just as Vivien is raped not long after discovering an intruder in her home, Chad is murdered by an intruder minutes after voicing his fear of a metaphorical one. This intrusion is also grounded in sexuality, as the intruder presents himself to the couple in the rubber fetish suit and sodomizes Patrick with the fire poker. Intrusion once again translates to sexual penetration. ${ }^{4}$

Sexual threat in the haunted house narrative rarely appears without (and is often implicitly paired with) the threat of class mixing - or even loss of social class. The walls of the house are meant to contain and protect women's sexuality; ideally, only those who are approved may enter and thus gain access to these women's lives. Socially acceptable persons are allowed in; undesirables are kept out. The haunted house story, however, perverts the purpose of confinement (Bailey, 1999: 4-6). With the gates to the afterlife wide open, the living inhabitants of the haunted house are subject to uncontrolled visitations from all manner of spirits.

Class is never explicitly explored in the first series of $A H S$, but it, like the evil of the Murder House itself, is a phenomenon from which the characters cannot escape. Indeed, the haunted house story as a genre has traditionally made issues of class an implicit requirement (Ibid.: 49). The house owes its origin as an abortion clinic to Nora Montgomery's fear of losing her social status; recognizing her husband's inability to continue his legal medical practice, Nora arranges for Charles to become an abortionist in an effort to rebuild the family's finances. Decades later, Nora's ghost will continue to take pride in the house's more expensive features, while lamenting the sterile, modernistic touches added by later tenants.

With the effects of the US housing market crash looming over the present-day storyline, the viewer should not be surprised when, halfway through the series, the Harmons are revealed to have tied up so much of their money in the house that they are financially powerless without it. Similarly, Chad and Patrick also entangled their finances with the house. Like the Harmons after them, Chad and Patrick had no choice but to attempt to maintain the house's 
Volume 5, Issue 2

September 2012

middle-class-gothic facade as their relationship continued to erode. The initial point of conflict between Chad and Patrick's ghosts and the Harmons lies in the Harmons' choice of Halloween decorations. For the Harmons, something as simple as holiday decorations offers the potential for another family to take an interest in buying the house, thus relieving them of it; for Chad and Patrick, a quaint, high-quality tableau creates a sense of cosy stability their relationship no longer had at the time of their deaths. With the hopes of both couples riding on the decorations, Halloween at the Murder House becomes steeped in class markers.

Gothic fiction has traditionally drawn connections between class and sexuality. At its core, Kate Ferguson Ellis argues, 'The conventions of the Gothic novel... speak of what in the polite world of middle-class culture cannot be spoken' (Ellis, 1989: 7). Ellis' assessment is equally applicable to Gothic visual culture. Despite its pleasant, mock-Edwardian exterior, the Murder House is the site of a number of 'deviant' sexual practices that stand in stark contrast to the Harmons' heterosexual, middle-class marriage - including, but not limited to, abortion, male homosexuality, BDSM, and rap. By the end of the first episode, however, Ben and Vivien have shared amused discomfort at finding the fetish suit that belong to Chad, and Vivien is raped by the Rubber Man. The family's move to a house in Los Angeles is explicitly an attempt to distance it from Ben's adulterous past but, once inside the house, the Harmons' marriage is only strained further, and Ben finds himself literally haunted by two beautiful women, one of whom is the ghost of his former lover. When the house immediately confronts him with his own adulterous desires via Moira, Ben engages in one of the episode's most unsettling moments, weeping uncontrollably while masturbating.

The classic haunted house story is intrinsically linked to the relationship between class and gender, as Ellis notes: 'The redefinition of "home" and woman's place in it that began in the middle of the eighteenth century addressed the issue of violence and danger in a new way. The world is a dangerous, violent place, but it is possible to exclude those elements from the home, and to keep women "innocent" of them' (Ibid.: 7-8). The irony of the haunted house story, as seen even in such contemporary examples as the Paranormal Activity (2007- ) and Amityville Horror (1979-1996, 2005) franchises, lies in the reversal of the site of danger; suddenly, the world outside poses less danger to female inhabitants than the home. In moving Vivien across the continent, Ben treats his adulterous behaviour as if it is outside their marriage, something which is bound physically to one place. By leaving that place (in this case, Boston), the Harmons hope to put Ben's affair and Vivien's ill-fated pregnancy behind them, only to find themselves in a house that offers Vivien a baby through a rape and Ben an affair through a ghostly maid, and which will physically bind Ben's lover to the family. Another ghost, Tate, sets his sights immediately upon the Harmon daughter. With ghosts moving freely inside the Murder House, both Vivien and Violet quickly become prey for sinister forces.

Ben's failure to protect his wife and daughter from the dangers represented within the house point toward a classic gothic emasculation. As the husband, father, financial provider of the Harmon clan, Ben is implicitly tasked with guarding the female inhabitants of his home from 
Volume 5, Issue 2

September 2012

the threat of those whose sexual and social statuses are undesired. In the Gothic tradition, Ellis writes, 'a well-regulated home... was an outward sign of male competence and trustworthiness.... It distinguished the middle class from the potentially dangerous lower orders, who could not afford it" (Ibid: x-xi). The modern haunted house story treats the establishment of class with irony by the fact that these houses' inhabitants often can only gain access to them when their dark pasts reduce their price (Bailey, 1999: 57).

The series offers several implied qualifiers regarding who is and is not allowed within the Harmons' protective walls. Both Tate and Addie are told to leave the house numerous times; Tate is incapable of leaving because his spirit is trapped on the house grounds, while Addie is drawn back to it because of her insatiable, if not a little morbid, curiosity, and her uncanny recognition of the house's supernatural state. These two seemingly benign intruders are the first, but certainly not the last, indication that the protection offered by the house is illusory, and Ben's role as the steward of the Harmon women has gone unfulfilled.

Two of the twelve episodes bear titles that explicitly draw attention to the house's protective purpose, 'Home Invasion' and 'Open House' (1.07). Three notable scenes feature a Harmon woman (Vivien in two cases, Violet in one) looking through the peephole of the house's thick, defensive front door and determining who may and may not enter - the horrific nature of these scenes lies in the viewers' knowledge that the women are powerless to actually keep anyone out. In the 1968 sequence of 'Home Invasion,' two sorority girls, one whose virginity is emphasized in both her name (Maria) and through her dialogue, lets in a man who claims to be injured; the man forces Maria to strip in front of him so that she can put on a nurse's uniform, after which he hogties her and stabs her to death. Present-day fans of the killer attempt to re-enact the scene with Vivien and Violet as their victims. When a woman claiming to be injured knocks on the Murder House's door at night, Vivien refuses her entrance, unaware that the woman's two partners are already breaking into the house. Though Ben allowed one of the would-be killers into the house earlier, he is no longer present to protect his wife and daughter, having just left for Boston to visit the Hayden. Left at the mercy of the morbid trio, Vivien and Violet are ultimately rescued by another intruder, Tate. (Addie also appears in the house and witnesses what is happening, but Constance, distracted by her lover, ignores Addie's report that the Harmons are in trouble.) Ignoring his phone, Ben has no idea that his wife and daughter are in danger until the following day, when, whilst Hayden is supposed to be undergoing an abortion, he checks his phone again. Learning what has happened back at home, Ben immediately leaves the clinic, abandoning Hayden, and, consequently, his expected role as a woman's protector.

The two-part 'Halloween' story $(1.04,1.05)$ is split by an unsettling cliff-hanger in which the impoverished and deformed Larry comes calling while Violet is home alone. Though Larry does not possess any supernatural abilities, he seems to realize that it may not be the Harmon patriarch on the other side of the door. 'Is that your daughter?' he asks, looking into the peephole as if he can see through it. The shot quickly switches to Violet, the Rubber Man standing behind her. While Larry does not harm Violet, the juxtaposition of his question with 
Volume 5, Issue 2

September 2012

the threatening figure of the Rubber Man behind the virginal teenager carries an implied danger of its own. Once again, Ben fails to rescue his daughter, and she is saved from any potential harm by Tate, who is free to leave the house due to the freedom granted to the dead on Halloween. In a perverse reversal of the heroic masculine paradigm, the innocent young woman's saviour is not the man whose function, in the gothic story, is to protect her from sexual harm, but rather, the psychotic intruder who raped her mother.

If the three unsavoury-looking thrillkillers, the poor, the burned man, the undesirable suitor, and the curious neighbour with Down syndrome are not allowed in the house, then who is? Undoubtedly, the Harmons may have valid reasons for not wanting the aforementioned characters in their home, but when juxtaposed against those who are allowed inside, the motley assortment of "undesirables" takes on a particularly social and sexual significance. Marcy (Christine Estabrook), the real estate agent whose career has unfortunately linked her to the Murder House, is welcomed into the Harmon home several times, and each time reveals increasingly darker attitudes toward sexual, ethnic, and social minorities. In 'Open House,' while showing around a prospective buyer, she refers to Chad and Patrick as the 'previous homos' rather than 'homeowners;' only minutes later, she reveals that she carries a gun in her purse because of her certainty that 'minority' men want to rape her. The Harmons have little choice but to allow the mouthpiece of such discriminatory attitudes inside if they want to be rid of the house.

Luke (Morris Chestnut), a security officer, is a welcome presence and even seems more capable of protecting the Harmon women than Ben. Where Ben, with Larry's help, inadvertently trapped Hayden and Vivien together, Luke arrests Hayden's ghost and tries to remove her from the house. His welcome is outworn, however, when Ben refuses to believe that Vivien was raped and instead assumes she had an affair with Luke. His immediate linking of Vivien's rape claim to sex with Luke recalls Marcy's own beliefs about the virility and sexual aggression of black men.

Two scenes in which the peephole serves as a portal between the the safety of the house and the dangers of the outside world have been discussed; in both scenes, those outside have appeared quite different from the Harmon women in terms of beauty standards and implied social ranking, and these 'intruders' are refused entry. The third such scene, ${ }^{5}$ however, ends with an invitation into the home. Following 'Home Invasion,' Vivien is understandably nervous about unexpected guests, but when the ghost of Nora Montgomery comes knocking, Vivien allows her in. Nora is an immediate contrast to the women of the previous episode, with fashionably mussed curls, makeup, and attractive clothing. More importantly, Nora recognizes the expensive Tiffany fixtures and elaborate woodwork the home boasts, revealing her knowledge of the home's worth and her refined tastes. At first, Vivien is defensive, telling Nora that her 'husband is upstairs, so...' but after seeing Nora's enjoyment of the house's sophisticated qualities, she quickly warms to her. 
Volume 5, Issue 2

September 2012

Ironically, it is Nora, along with Hayden, who will become the greatest threat to Vivien as the series progresses. The episode 'Rubber Man' reveals that Tate's rape of Vivien was a dark favour to Nora, who wishes for an inhabitant of the home to become pregnant so that she might steal the baby. Once he has impregnated Vivien, Tate has no further interest in her; rather, it is the attractive, middle-class women who seek to harm Vivien (Hayden's financial state is suggested by her sizable apartment in a major city, as well as the ease with which she followed Ben across the country, neither of which is easily accomplishable for many US students, who receive little to no financial aid for university education). Also desiring a baby, Chad and Patrick plan to steal Vivien's twins, but never seem a viable threat due to the distraction of their stormy relationship. As the series prepares for its climax, the only real danger is posed by heterosexual, middle-class women.

\section{The Rubber Man}

Many viewers were already familiar with the dark, latex-encased figure even before $A H S$ began airing thanks to the show's advertising campaign, which deployed television commercials, online videos, and even an interactive website (www.youregoingtodieinthere.com) that offered users "clues" to discover potential plot points. Though the Rubber Man is but one of the series' many ghosts, he appeared in several promotional materials, identifying him as the chief villain of the upcoming show. With other ghosts spending most of their time worrying about the Murder House's decorations and parenthood, it is no surprise that the Rubber Man's malevolent role in the story should be emphasized. However, what makes his prominence especially notable is his costume. Unlike the other characters who haunt the Harmons' house, the Rubber Man seems to have no human identity in $A H S$ 's promotional campaign; he is an entity without a true name, only a label that corresponds to his fetish suit.

One of the most popular images used to advertise the series is that of Vivien and the Rubber Man in a red room. Heavily pregnant, Vivien lies on the floor, wearing only black lingerie. The Rubber Man emerges through the ceiling, reaching toward Vivien's swollen stomach. The Rubber Man's body is bent at a painfully sharp angle, and the ripples of the suit's zipper create the illusion of a deformed spine. It is certainly an eye-catching image, both tantalizing and unsettling, but, in terms of the show's actual plot, misleading when it suggests the Rubber Man's interest in Vivien's unborn children. The Rubber Man may be the father of one of Vivien's twins, but he lacks the aggressive desire for a child that causes the ghosts of Nora, Hayden, Chad, Patrick, and the living Constance to try to steal the babies. An image of any of these characters reaching toward Vivien, however, would hardly be as frightening as that of a figure in a fetish suit.

Murphy recognized the Rubber Man's potential prior to the script's completion. The inspiration for character, according to Murphy, came as a result of his visit to 'some weird bookstore,' in which he 'saw a book on how to care for your fetish suit. On the cover was this 
Volume 5, Issue 2

September 2012

gleaming suit' (qtd. in Stack, 2011). By the time Murphy began working on the show's pilot episode with Brad Falchuk, Murphy claims to have been 'obsessed' with the black rubber figure (Stack, 2011).

Fascination with the fetish suit, and the Rubber Man it would become, may be behind Murphy's development of $A H S$ 's most visible villain, but the dark figure easily finds a home in a Horror story due to public anxiety. While even small adult stores in the US carry generic items with sadomasochistic connotations (like riding crops), BDSM practices themselves have not yet gained public approval. Eleanor Wilkinson cites popular uses of BDSM elements in visual media as evidence that this form of sexuality is still largely considered unacceptable and/or abnormal: "The very fact that advertisers are using SM imagery in an advertising campaign... highlights that it is still seen as a "deviant" and "naughty" pastime. This approach to advertising only "works" because SM is still a taboo; it is what makes it a controversial campaign" (2009: 183). ${ }^{6} A H S$ made heavy use of such imagery; indeed, a plot revealed on the promotional website (which was never explored on the show itself) was steeped in BDSM. One scene in the interactive website tells, through photographs, video, and a partial police report, the story of a couple who are killed in a BDSM sexual encounter. The video (labelled 'Perverted Video') and final photographs reveal that an unseen third person actually killed them. Whether any of the BDSM elements of the scene were consensually chosen by the couple prior to the attack or were simply forced upon them is not revealed. The police report emphasizes the presence of BDSM elements, such as props and bodily positions. From the outset, the series promised to incorporate BDSM into its exploration of horror; whether or not it did so with respect to actual BDSM practice is left to the audience to determine.

Tate's co-opting of the fetish suit for rape and murder points toward the character's own misunderstanding of BDSM practices, one that perhaps mirrors the frightening and violent connotations BDSM may have for those who are not already familiar with such practices. The actual purpose of the fetish suit, the shop owner who sells it to Chad points out, is 'to dehumanize the submissive, to turn him into a rubber sex toy' ('Rubber Man'). It should also be noted that this particular type of fetish suit is known for limiting the wearer's ability to move and sometimes even to breathe; openings are typically placed in areas meant to be penetrated (eyeholes can be optional). When Tate claims the suit for his own purposes, he removes it from its actual BDSM use and places it into public consciousness as an object of horror, the costume of a sexual aggressor.

\section{Subversions}

With Murphy's other ongoing series, Glee, being lauded for its inclusion of gay characters and praise for other recent gay-themed series like Queer as Folk (2000-2005), The L Word (2004-2009), and Six Feet Under (2001-2005) (to name but a few), we may wonder if $A H S$ 's presentation of sexuality as the base element of horror truly serves a positive function. On 
Volume 5, Issue 2

September 2012

one hand, the series provokes discussion of issues like abortion, pregnancy, adultery, and homosexuality in the domestic sphere, but do its methods actually challenge viewers' preconceptions? Or do they simply rely on sexual shock to create the unsettling environment in which horror flourishes?

Representations of BDSM and male same-sex relationships in the series warrant the most scrutiny. Though purchased in an attempt to reclaim a lover, the rubber fetish suit is a sign of villainy throughout the series, with Tate quickly co-opting it for his own psychotic purposes. While the donning of a "second skin" costume is not unique in Horror (recall Leatherface in Texas Chainsaw Massacre (1974), Buffalo Bill in The Silence of the Lambs (1991) and more recently, Otis's cruel prank in House of 1000 Corpses (2003)) ${ }^{7}$, Tate's use of the fetish suit, an artefact of a very specific sexual community, removes it from its intended use to make it a villain in and out of itself. Even when he means to court Violet, he nonetheless dons the suit for no real narrative purpose, but rather to make the viewer fear that Violet is about to be harmed by the sinister figure who raped her mother in the first episode. Chad is unsettled by the suit and purchases it only when the shop owner convinces him that his partner will enjoy it; instead, Patrick hates the suit, leaving Chad humiliated to be wearing it. Vivien is surprised when she believes Ben is wearing the suit, but she is clearly aroused by the prospect of something so new in the bedroom. Her arousal is made perverse through the revelation that it was a (supernatural) stranger, not her husband, in the suit. In the series' final episode (1.12, 'Afterbirth'), Ben does don the suit - and makes a mock sexual attack on the new woman in the house.

That his method of scaring the house's new residents mimics Tate's actual assault on his wife becomes something of a joke at the episode's end. Still wearing the fetish suit, Ben presents himself as a villain to frighten the new couple but, once the living residents have fled, he and Vivien laugh and move to embrace over their victory. Tate can only watch from the shadows as the Harmon family continues living peacefully and happily, powerless now that he is no longer the Rubber Man.

Though the series does seem to superficially villainise BDSM practices, 'Afterbirth' offers the possibility of a new reading. A middle-class, heterosexual couple now owns the suit, and once it has passed into their ownership, it is stripped of its destructive potential. Ben's adoption of it to frighten new residents seems to mock his own anxieties at the sight of the suit in the first episode. Previous appearances of the suit have allied it simultaneously with violent men and discriminatory beliefs about the "perversions" of gay men. 'Afterbirth,' however, places the suit in the Harmons' custody, and implicitly argues for the normalcy of BDSM practices when, as the new family flees the Murder House, Ben appears with Vivien and Violet, now wearing his typical middle-class attire. The heterosexual nuclear family is also a family that engages in BDSM play from time to time.

The show's depiction of gay men is similarly cause for critical attention. With its emphasis on infidelity, the relationship between Chad and Patrick can hardly be considered positive or 
even stable. Several classic stereotypes of gay men's representations manifest in $A H S$ 's resident gay couple, most notably Patrick's use of the gym for meeting new sexual partners and Chad's intense love of decorating. Both men give camp performances (Butler, 1990), tempering masculine sexual prowess with feminine gestures to the point of caricature in a manner that recalls classic television depictions (Loftin, 2007). Chad's previously-discussed disdain for Vivien seems to play on anxieties about misogyny amongst gay men, while Patrick's attempt to seduce Ben, despite Ben's protests of heterosexuality, plays on fears of aggressive gay "recruiters." In some ways, Chad and Patrick aren't so very different from the negative representations of coded gay men in classic visual media, whose implied sexuality was cause for humorous disdain (Netzley, 2010: 969). ${ }^{8}$ Netzley notes that, in mid-twentieth century film and television, the place of the gay man was typically to serve as either murderer or victim (Netzley, 2010: 969), both of which identify Chad and Patrick when they are first introduced as the participants of a murder-suicide, and which are emphasized when their actual fate is revealed.

In more recent years, queer-themed television has come under scrutiny for portraying gay men as sterile characters, whose sexuality is presented as part of their identity but is never explored, nor often even depicted. Gay and lesbian sex has usually been relegated to shows on American premium television stations (Queer as Folk and The L Word aired on Showtime, ${ }^{9}$ Six Feet Under on HBO). Popular representations of gay men on cable television sitcoms like Will \& Grace (1998-2006) and reality shows like Queer Eye for the Straight Guy (2003-2007) have been criticized for depicting gay sexuality as something that happens offscreen and is never discussed, the gay man often seeming more like asexual props for straight characters (Alexander, 2010; Avila-Saavedra, 2009; Clarkson, 2008; Raley and Lucas, 2006). Even the simplest gay sexual performances, such as kissing, often fail to appear in primetime television (Netzley 2010: 980).

There is certainly a lack of kissing between gay men in $A H S$, but gay sexuality does receive fairly frank discussion. Explicit references to sexual practices, such as anal sex, confront viewers, rather than leaving audiences to image what might happen between two men in the bedroom. As Chad fulfils the function of the gay male decorator, Patrick further rejects feminised, middle-class, asexual stereotypes of gay men: 'Everything we've become is bullshit. I don't give a shit about carving pumpkins. I want love, I want passion, I want a relationship with a man, not Martha Stewart' ('Halloween: Part I'). A later episode expounding upon the same scene sees Patrick aggressively exposing the falseness of stereotypes of gay domesticity and forces viewers to imagine gay anal sex: 'The house, decorating, I hate it. It's no wonder I don't want to stick my dick in you anymore' ('Rubber Man'). His vitriolic words transcend character dialogue to make an indictment against popular gay male characterizations. Gay men, Patrick's lines implicitly argue, do not have to be middle-class, do not have to be domestic gods, do not have to be feminised, and do not have to be sterile. Moreover, through spreading Chad and Patrick's appearance throughout the series and reintroducing them in the story's final conflict, $A H S$ continually breaks from a 
Volume 5, Issue 2

September 2012

television paradigm, which Netzley describes as a 'once and done appearance [that] can allow programs to present gay characters as an anomaly or to spark a discussion on gay issues that concludes at the end of the hour and isn't picked up again the following week' (Ibid.: 981). Just as Constance can't 'get rid of the gays' (1.11, 'Birth'), $A H S$ 's regular audience cannot ignore the presence not only of gay characters, however camp they may be on occasion, but also of gay sex itself.

\section{Conclusion}

In terms of exploring interrelated issues of class and sexuality, $A H S$ appears to attempt a progressive discussion, but remains problematic. Implicit arguments against the asexuality of gay men are appreciable but made somewhat weaker by the show's abrupt depiction of sex between women as something that occurs to entice and/or betray men. The reestablishment of the rubber fetish suit as belonging to a 'normal' (i.e. heterosexual, middle-class) family lasts only for a short period, after which the suit disappears; the majority of its uses are villainous, and we should remember that even the character who purchased it expressed discomfort with it. Anxieties about abortion are somewhat addressed, but no true argument seems to be made. The treatment of Moira's rape as a consensual act is highly problematic; Moira's own description of herself as a 'tramp' ('Afterbirth') and her promiscuity are never juxtaposed against the rape, but rather, she continues to be blamed for the rape by Constance, and may, the show implies, even blame herself. With three notable exceptions, the ambition of the show's women is become a mother. Moira and Violet are both prevented from joining the would-be mothers due to their ages. Addie is another exception and, while the show does begin an interesting debate on sexual agency and those with Down syndrome, that debate only occupies a couple of minutes in two scenes, and is never broached again.

However, the show does arguably succeed in introducing challenges to mainstream television audiences' sexual anxieties. Foucault's noted Victorian imperative that aberrant sexualities stay out of sight and out of mind (Foucault, 1978: 4), still a powerful force in entertainment media today, is recognized, synthesized, and ultimately threatened throughout the series. Moreover, the series presents an argument for the abjection of everyday, domestic traumas, horrific in their own right, which are here translated into supernatural horror elements. The monster in $A H S$ 's closet is middle-class sexualities, but what makes it monstrous is not its nature but rather how such sexualities have been traditionally interpreted. The final image of the Harmons creates an unexpected site of anxiety - here is a middle-class, heterosexual family... but they are dead, and the husband wears a fetish suit.

\section{References}

Alexander, J. (2010) 'Straight Eye for the Queer Guy: Composing Queerness', Journal of Homosexuality, 57 (6), pp.697-729. 
Volume 5, Issue 2

September 2012

Anon. (2011) http://www.youregoingtodieinthere.com [Accessed 2012, October 2].

Anon. (2011, October 4) 'Michele Bachmann Responds to Gay Bullying Petition: "Bullying is Wrong," Huffington Post. Available at

http://www.huffingtonpost.com/2011/10/04/michele-bachmann-responds_n_994995.html

[Accessed 2012, June 7].

Arthurs, J. (2004) Television and Sexuality: Regulation and the Politics of Taste. Berkshire: Open University Press.

Avila-Saavedra, G. (2009) 'Nothing Queer about Queer Television: Televized Construction of Gay Masculinities,' Media, Culture, \& Society, 31 (1), pp.5-21.

Bailey, D. (1999) American Nightmares: The Haunted House Formula in American Popular Fiction. Bowling Green: Bowling Green University Press.

Butler, J. (1990) Gender Trouble: Feminism and the Subversion of Identity. London: Routledge.

Clarkson, J. (2008) 'The Limits of the Discourse of Norms: Gay Visibility and Degrees of Transgression,' Journal of Communication Inquiry, 32 (4), pp.368-382.

Creed, B. (1993) The Monstrous Feminine: Film, Feminism, Psychoanalysis. London: Routledge.

Ellis, K. (1989) The Contested Castle: Gothic Novels and the Subversion of Domestic Ideology. Urbana: University of Illinois Press.

Erdley, S. (2012) 'One Town's War on Gay Teens,' Rolling Stone. February 2, Available at http://www.rollingstone.com/politics/news/one-towns-war-on-gay-teens-20120202 [Accessed 2012, June 7].

Freydkin, D. (2011) 'The True "Horror" of It: McDermott in Latex,' USA Today. October 18, Available at http://www.usatoday.com/life/people/story/2011-10-18/dylan-mcdermottamerican-horror-story/50819280/1 [Accessed 2012, June 7].

Foucault, M. (1990 [1978]) The History of Sexuality Volume I: An Introduction. New York: Vintage.

Guttmacher Institute (2012 [2011]). 'U.S. Teenage Pregnancies, Births, and Abortions:

National and State Trends and Trends by Race and Ethnicity.' Available at http://www.guttmacher.org/pubs/USTPtrends.pdf [Accessed 2012, June 7].

Horovitz, B. (2005) 'NFL Strives to Ensure Superclean Super Bowl,' USA Today. January 20, Available at http://www.usatoday.com/money/2005-01-20-bowl-cover_x.htm [Accessed 2012, June 7]. 
Volume 5, Issue 2

September 2012

Kristeva, J. (1982) Powers of Horror: An Essay on Abjection. Available at http://www.csus.edu/indiv/o/obriene/art206/readings/kristeva\%20\%20powers\%20of\%20horror\%5B1\%5D.pdf [Accessed 2012, June 7].

Loftin, C. (2007) 'Unacceptable Mannerisms: Gender Anxieties, Homosexual Activism, and Swish in the United States, 1945-1965,' Journal of Social History, 40 (3), pp.577-596.

Mencimer, S. (2011) 'The Teen Suicide Epidemic in Michele Bachmann's District,' Mother Jones. July 25, Available at http://www.motherjones.com/politics/2011/07/michelebachmann-teen-suicide [Accessed 2012, June 7].

Netzley, S. (2010) 'Visibility that Demystifies: Gays, Gender, and Sex on Television,' Journal of Homosexuality, 57, pp.968-986.

Raley, A. and Lucas, J. (2006) 'Stereotype or Success? Prime-Time Television's Portrayals of Gay Male, Lesbian, and Bisexual Characters,' Journal of Homosexuality, 51 (2), pp.19-38.

Stack, T. (2011) 'American Horror Story,' Entertainment Weekly. October 21, Available at http://www.ew.com/ew/article/0,20534121_20538832,00.html [Accessed 2012, June 7].

Wiley, D. and Wilson, K. (2009) 'Just Say Don't Know: Sexuality Education in Texas Schools,' Texas Freedom Network Education Fund. Available at http://www.tfn.org/site/DocServer/SexEdRort09_web.pdf?docID=981 [Accessed 2012, June 7].

Wilkinson, E. (2009) 'Perverting Visual Pleasure: Representing Sadomasochism,' Sexualities, 12 (2), pp.181-198.

\section{Teleography}

American Horror Story. (2011- ) U.S.A.: $20^{\text {th }}$ Century Fox Television.

- 'Pilot,' American Horror Story. Episode 1.01. Dir. Ryan Murphy. FX. 2011, October 5.

- 'Home Invasion,' American Horror Story. Episode 1.02. Dir. Alfonso Gomez-Rejon. FX. 2011, October 12.

- 'Murder House,' American Horror Story. Episode 1.03. Dir. Bradley Buecker. FX. 2011, October 19.

- 'Halloween: Part I,' American Horror Story. Episode 1.04. Dir. David Semel. FX. 2011, October 26.

- 'Halloween: Part II,' American Horror Story. Episode 1.05. Dir. David Semel. FX. 2011, November 2.

- 'Piggy Piggy,' American Horror Story. Episode 1.06. Dir. Michael Uppendahl. FX. 2011, November 9. 
Volume 5, Issue 2

September 2012

- 'Open House,' American Horror Story. Episode 1.07. Dir. Tim Hunter. FX. 2011, November 16.

- 'Rubber Man,' American Horror Story. Episode 1.08. Dir. Miguel Arteta. FX. 2011, November 23.

- 'Spooky Little Girl,' American Horror Story. Episode 1.09. Dir. John Scott. FX. 2011, November 30.

- 'Birth,' American Horror Story. Episode 1.11. Dir. Alfonso Gomez-Rejon. FX. 2011, December 14.

- 'Afterbirth,' American Horror Story. Episode 1.12. Dir. Bradley Buecker. FX. 2011, December 21.

Doctor Who. (1963-1989) U.K.: British Broadcasting Corporation.

Doctor Who. (2005- ) U.K./Canada: British Broadcasting Corporation/Canadian Broadcasting Corporation.

Glee. (2009- ) U.S.A.: 20th Century Fox Television/Ryan Murphy Productions/Brad Falchuk Teley-Vision.

The L Word. (2004-2009) Canada/U.S.A.: Anonymous Content/Dufferin Gate Productions/Viacom Productions/Showtime Networks.

Nip/Tuck. (2003-2010) U.S.A.: Warner Bros. Television/Stu Segall Productions/The Shephard $\backslash$ Robin Company/Ryan Murphy Productions/Hands Down Entertainment.

Queer as Folk. (2000-2005) U.S.A./Canada: Cowlip Productions/Tony Jonas

Productions/Temple Street Productions/Showtime Networks/QAF V Productions.

Queer Eye for the Straight Guy. (2003-2007) U.S.A.: Scout Productions/Bravo Original Production.

Six Feet Under. (2001-2005) U.S.A.: Home Box Office/The Greenblatt Janollari Studio/Actual Size Films/Actual Size Productions.

Twin Peaks. (1990-1991) U.S.A.: Lynch/Frost Productions/Propaganda Films/Twin Peaks Productions/Spelling Entertainment.

Will \& Grace. (1998-2006) U.S.A.: NBC Studios/Everything Entertainment/KoMut Entertainment/New Dominion Pictures/Three Sisters Entertainment/NBC Universal Television/Outdoor Life Network.

The X-Files. (1993-2002) U.S.A./Canada: 20th Century Fox Television/Ten Thirteen Productions/X-F Productions.

\section{Filmography}


Volume 5, Issue 2

September 2012

Fatal Attraction. (1987) Dir. Adrian Lyne. U.S.A.: Paramount Pictures.

House of 1000 Corpses. (2003) Dir. Rob Zombie. U.S.A.: Universal Pictures/Spectacle Entertainment Group.

Rosemary’s Baby. (1968) Dir. Roman Polanski. U.S.A.: William Castle Productions.

The Silence of the Lambs. (1991) Dir. Jonathan Demme. U.S.A.: Orion Pictures

Corporation/Strong HeartlDemme Production.

The Texas Chain Saw Massacre. (1974) Dir. Tobe Hooper. U.S.A.: Vortex.

\footnotetext{
${ }^{1}$ Murphy lists the Saw (2004-10) and Hostel (2005-11) franchises as examples of the hyperviolent, gorefocused Horror movies that have become popular in the genre. Conversely, the films he counts among his favourites include Fatal Attraction (1987) and the pregnancy-themed Rosemary's Baby (1968).

${ }^{2}$ When asked to respond to these accusations of responsibility, Bachmann expressed concern that prohibiting sex-based bullying would be "stifling free speech and expression" (Anon., 2011, October 4).

${ }^{3}$ While male failure to protect women and children is a common element in Horror movies in general, it is especially notable in tourists stories and haunted house stories. A recent example of the latter is the Paranormal Activity franchise (2007-), in which, despite living with a malevolent spirit's intended victim, the family patriarch is unable to prevent wicked forces from abusing his charges in his own home.

${ }^{4}$ There are a number of stories that appear on the interactive website created to promote the show, www.youregoingtodieinthere.com, that do not feature in the series itself. In the 2000 s, the final room of the house is full of 'clues' about an inhabitant, identified only as V., who is morbidly obsessed with the threat of disease. In a series of letters labelled 'Love Notes,' V. writes to her partner regarding the necessity of disinfection. The letters become increasingly paranoid, until near the end, V. has become convinced that germs have infiltrated the "barrier" of their home. Patterns in Petri dish cultures spell out the word "unclean" on the desk.

${ }^{5}$ Chronologically, the scene in which Nora visits the home comes second, but is labelled the third scene here for purposes of discussion of the juxtaposition between who is and who is not allowed in the Harmon home.

${ }^{6}$ Wilkinson here refers to an ad campaign for the BMW Mini. I would argue that an even more prominent examples of the uses of BDSM imagery to advertise a product are those of pop stars like Lady Gaga and Rihanna, both of whom have invented, however authentic, celebrity personas that frequently engage in explicit or implicit BDSM practices.

${ }^{7}$ These skins are, in fact, more literal than the rubber fetish suit of $A H S$. Leatherface wears a mask stitched together from the skins of his family's victims. Though he never finishes his project, the entire purpose of Buffalo Bill's kidnapping and murder spree is to create a full-body suit of human skin. To taunt one of his victims, Otis Firefly creates a mask out of the severed facial tissue of the girl's father.

${ }^{8}$ Loftin and Netzley's articles both provide detailed examples of classic camp representations.

${ }^{9}$ It should perhaps be noted that both Queer as Folk and The L Word, while receiving a mostly positive response from queer communities, have been criticized for depicting gays and lesbians as hypersexual and promiscuous.
} 